De Jure: Jurnal Hukum dan Syar'iah

Vol. 12, No. 1, 2020, h. 64-85

ISSN (Print): 2085-1618, ISSN (Online): 2528-1658

DOI: http://dx.doi.org/10.18860/j-fsh.v12i1.8796

Available online at http://ejournal.uin-malang.ac.id/index.php/syariah

\title{
The Effect of Cancellation of Regional Regulations on Retribution Toward Regional Financial Regency In West Java
}

\author{
Uu Nurul Huda \\ UIN Sunan Gunung Djati Bandung \\ uunurulhuda@uinsgd.ac.id
}

\begin{abstract}
:
Law no. 12 of 2011 concerning the Formation of Legislation Regulations has established provincial and regencies / city regional regulations in the hierarchy of laws and regulations as well as regional legal products. In order to explore regional financial resources, regencies / cities can issue regional regulations regarding regional user fees. However, the presence of local regulations on retribution in several regencies / cities often results in problems in the community because the presence of these regulations will add burden to the community concerned and / or conflict with higher policies or regulations. On this basis the government through the Ministry of Home Affairs conducted supervision and many canceled the regional regulation on retribution in various regions including regencies / city areas in West Java. This paper aims to analyze the authority and purpose of the cancellation of regional regulations and their effects on the regencies / city financial area in West Java. This study uses an empirical juridical approach with descriptive analysis in analyzing the research problems. The results of the study showed that the cancellation of the regulation on retribution was intended as a repressive effort by the central government so that the regions were not too far in making the regulation on retribution, the central government had the authority to conduct supervision and guidance by reviewing provincial and regencies / city regional regulations, in addition to judicial review by the Supreme Court. The existence of the cancellation of regional regulation on retribution has an effect on the loss of Regional Original Revenue (PAD) as a source of regional finance. The loss of retribution also affects the level of effectiveness and efficiency of local government administration, especially in aspects that are supported by the retribution budget.
\end{abstract}

Keywords: retribution; regional regulations; law.

\section{Abstrak:}

UU No. 12 Tahun 2011 tentang Pembentukan Peraturan Perundang-undangan telah menetapkan peraturan daerah provinsi dan kabupaten/kota dalam hierarkhi 
peraturan perundang-undangan sekaligus sebagai produk hukum daerah. Dalam rangka menggali sumber keuangan daerah, kabupaten/kota dapat menerbitkan peraturan daerah mengenai retribusi daerah. Namun, hadirnya perda retribusi di beberapa kab/kota sering mengakibatkan persoalan di masyarakat karena hadirnya perda tersebut akan menambah beban bagi masyarakat yang berkepentingan dan/atau bertentangan dengan kebijakan atau aturan yang lebih tinggi. Atas dasar itulah pemerintah melalui Kementerian Dalam Negeri melakukan supervisi dan banyak membatalkan perda retribusi di berbagai daerah termasuk daerah kabupaten/kota di Jawa Barat. Tulisan ini bertujuan untuk menganalisis kewenangan dan tujuan pembatalan perda retribusi dan pengaruhnya terhadap keuangan daerah kabupaten / kota di Jawa Barat. Penelitian ini menggunakan pendekatan yuridis empiris dengan analisis deskriptif dalam menganalisis permasalahan penelitian tersebut. Hasil penelitian menunjukkan bahwa adanya pembatalan perda retribusi dimaksudkan sebagai upaya represif pemerintah pusat agar daerah tak kebablasan dalam membuat perda retribusi, pemerintah pusat memiliki kewenangan untuk melakukan pengawasan dan pembinaan dengan melakukan review terhadap peraturan daerah provinsi dan kab/kota, di samping judicial review oleh Mahkamah Agung. Adanya pembatalan peraturan daerah retribusi berpengaruh pada hilangnya Pendapatan Asli Daerah (PAD) sebagai salah satu sumber keuangan daerah. Hilangnya retribusi juga berpengaruh pada tingkat efektifitas dan efisiensi penyelenggaraan pemerintahan daerah, terlebih pada aspek yang ditunjang anggarannya oleh retribusi tersebut.

Kata Kunci: retribusi; peraturan deaerah; hukum.

\section{Introduction}

After the amendment to the 1945 Constitution, relations between the center and the regions experienced a shift from a centralized system to a decentralized system. The existence of this shift aims to strengthen the system of the Unitary State of the Republic of Indonesia (NKRI) regulated in Article 18 paragraph (1) of the 1945 Constitution that the Unitary State of the Republic of Indonesia is divided into provincial regions and provincial regions divided into districts and cities, each province, regencies, and cities have regional governments, which are regulated by law.

The provision of Article 18 paragraph (1) of the 1945 Constitution confirms that the implementation of regional government is carried out with the principle of autonomy and the task of assistance based on the laws that govern it. To carry out the principle of autonomy, the regional governments, both provincial and district/city, are given the authority to regulate and manage regional government affairs through regional legal product instruments, namely regional regulations. This is also reinforced by Article 18 paragraph (6) of the 1945 Constitution that Regional Governments have the right to stipulate regional regulations and other regulations to carry out autonomy and assistance tasks. This rule further emphasizes the existence of a constitutional power because it is stipulated explicitly in the 1945 Constitution.

Seeing the strong existence of constitutional regulation, in the case of the formation of local regulations and other regulations in the regions, they must still be subject to and must not conflict with the hierarchical system of laws and regulations that have been regulated in Article 7 paragraph (1) of Law no. 12 of 2011 concerning the Formation of Regulations and Regulations. For the regional 
regulation to be subject to a hierarchical system, Article 24A paragraph (1) of the 1945 Constitution stipulates that "the Supreme Court has the authority to decide at the cassation level, examine the statutory provisions under the law against the law, and have other authorities granted by law invite". The existence of this authority confirms that the Supreme Court functions as the judicial power, which can examine the legal norms materially under the law against the law, including bylaws. The authority of the Supreme Court to consider the material provisions of the legislation under the law is called the "Judicial Review".

The authority to examine the statutory provisions under the law against the said law is also regulated in Article 11 paragraph (2) letter b of Law No. 4 of 2004 concerning Judicial Power, that "the Supreme Court has the authority to examine the statutory provisions under the law against the law". The legal remedies in this test are carried out by examining the cassation level, as stipulated in Article 11 paragraph (3) of Law no. 4 of 2004, that "The statement does not apply legislation as a result of testing as referred to in paragraph (2) letter b can be taken in the examination of the cassation level or based on a direct request to the Supreme Court".

However, within the framework of the Unitary Republic of Indonesia, the central government has the authority to provide guidance and supervision to regional governments. Based on this authority, the government, based on Law No. 23 of 2014 concerning the Regional Government, has the authority to cancel the Regional Regulation. Ni'matul Huda believes that the supervision of the Government is related to the principles of regional autonomy and the task of assistance mandated in the Law on Regional Government, namely (a) the implementation of regional autonomy is carried out with due regard to aspects of democracy, justice, equity, as well as regional potential and diversity, (b ) the implementation of regional autonomy is based on broad, real and responsible autonomy, (c) the implementation of wide and complete regional autonomy lies in the regency and city areas, while the provincial region is a limited autonomous region. ${ }^{1}$

Article 250 paragraph (1) of Law No. 23 of 2014 concerning the Regional Government stipulates that the Government can cancel the Regional Regulations and Regional Regulations that conflict with the provisions of higher laws, public interests, or decency. According to Jimly Asshiddiqie, the cancellation of the Peraturan Pemerintah that was carried out in the context of Government supervision of the regions was a natural thing, because of the regional government as part of a state institution under the coordination of the Ministry of the Interior. ${ }^{2}$

Related to the Government's authority to cancel the Regional Regulations and Regional Regulations has invited debate among legal experts. Jimly Asshiddiqie believes that the supervision of regional legal products carried out by the Government does not have to cancel or revoke regional legal products, because the legal products produced by the Regional Head and Regional Representative Council in the form of Regional Regulations and legal products formed by Regional Heads in the form of Regional Regulations cannot be canceled unilaterally by the

\footnotetext{
${ }^{1}$ Ni'matul Huda, Desentralisasi asimetris dalam Negara Kesatuan Republik Indonesia: kajian terhadap daerah istimewa, daerah khusus, dan otonomi khusus (Bandung: Nusa Media, 2014), 22.

${ }^{2}$ Jimly Asshiddiqie, Konstitusi \& konstitusionalisme Indonesia (Jakarta: Konstitusi Press, 2006), 125.
} 
Government. The government should not be given the authority to cancel local legal products, because this is the constitutional authority of the Supreme Court (judicative) based on Article 24A paragraph (1) of the 1945 Constitution. ${ }^{3}$

A different view was expressed by Sri Soematri who argues that there are various ways of canceling regional legal products (Regional Regulations) because the test rights are carried out not only by the Supreme Court but also by the Government (President) and also by the Minister of Home Affairs. ${ }^{4}$ Minister of Home Affairs argues that it is natural when the Government cancels a Regional Regulation. This is done as a form of supervision of the implementation of regional autonomy in carrying out decentralization and supporting tasks. ${ }^{5}$ In fact, up to 2014, the Government, through the Ministry of Home Affairs, had canceled 9000 regional legal products that were considered to conflict with the public interest (investment) or higher laws and regulations. ${ }^{6}$ When compared, the number of legal products canceled by the Government with regional legal products submitted by the applicant to the Supreme Court is very far in comparison. Only 17 Regional regulations were submitted for material testing in $2014^{7}$ and 10 regional regulations in $2015 .^{8}$

In 2016, the Government re-evaluated and canceled 3,143 Regional Regulations and Local Elections, which were deemed problematic. President Jokowi reasoned that the Regional Regulation were canceled because the Regional Regulation were related to economic development in the regions, especially related to the business and investment world. Jokowi said the revoked regulations include: Regulations that are considered to hamper economic growth in the region and extend bureaucratic pathways, Regulations that impede the licensing and investment process as well as Regulations which are considered to conflict with higher laws and regulations. It is hoped that through the annulment of Regional Regulations, it is hoped that Indonesia will become a large, tolerant, and competitive nation. ${ }^{9}$ The government's move to cancel thousands of regional regulations with the reasons stated above were criticized by Jimly Asshidiqie. Jimly argues that the reason for the cancellation of the regional regulation should be based on legal logic, not economic logic, or investment reasons. Our goal as a state is not just welfare. We need freedom, justice, unity, or brotherhood. Economics

\footnotetext{
${ }^{3}$ Asshiddiqie, 37-39.

${ }^{4}$ Sri Soemantri Martosoewignyo, Hukum tata negara Indonesia: pemikiran dan pandangan (Bandung: Remaja Rosdakarya, 2014), 102.

${ }^{5}$ Leo Agustino, 'Pembatalan 3.143 peraturan daerah: satu analisis singkat', CosmoGov: Jurnal Ilmu Pemerintahan 3, no. 1 (29 April 2017): 25, https://doi.org/10.24198/cosmogov.v3i1.12405.

6 Akhmad Khalimy, 'Pencabutan Peraturan Daerah Dalam Timbangan Negara Hukum', Mahkamah: Jurnal Kajian Hukum Islam 2, no. 1 (11 June 2017): 31, https://doi.org/10.24235/mahkamah.v2i1.1617.

${ }^{7}$ Mahkamah Agung RI, Laporan Tahunan Mahkamah Agung Republik Indonesia Tahun 2014 (Jakarta: Mahkamah Agung, 2015), 68.

${ }^{8}$ Mahkamah Agung RI, Laporan Tahunan Mahkamah Agung Republik Indonesia Tahun 2015 (Jakarta: Mahkamah Agung, 2016), 60.

9 Human Sekretariat Kabinet, 'Kemendagri Resmi Umumkan 3.143 Perda Yang Dibatalkan', Sekretariat Kabinet Republik Indonesia, 21 June 2016, https://setkab.go.id/kemendagri-resmiumumkan-3-143-perda-yang-dibatalkan/.
} 
only counts. While the law determines. So, what is used is a clear reason that is legal criteria, do not use the term investment. ${ }^{10}$

The implication of canceling thousands of regional regulations, especially those related to regency/city regulations regarding regional retribution, might have an impact on regional finances. By Article 279, paragraph (2) of Law no. 23 of 2014, that: (1) The Central Government has a financial relationship with the Region to finance the implementation of Government Affairs, which are submitted and/or assigned to the Regions; (2) Economic relations in the administration of Government Affairs which are submitted to the Regions as referred to in paragraph (1) include: a) providing regional revenue sources in the form of regional taxes and regional retribution; b) the provision of funds comes from a financial balance between the Central and Regional Governments; c) granting funds for the implementation of special autonomy for individual Regional Governments stipulated in the law; Ana d) lending and/or grants, emergency funds, and (fiscal) incentives..

Based on the provisions of Article 279 paragraph (2) letter above, it is evident that in the context of financial relations in the administration of Government Affairs, which are submitted to the Regions is the granting of Regional revenue sources in the form of regional taxes and retribution. The existence of such authority shows the existence of the principle of decentralization by issuing regional financing arrangements through the APBD to carry out government affairs which are the regional authority. That is the source of APBD funds, in addition to sourcing from local levies (tax assignment), also from the revenue sharing funds (revenue sharing) and financial assistance (grants) or known as balanced funds as a source of funds for the APBD.

Thus, regional retribution are a source of the regional revenue, the arrangements made by the region. Furthermore, Article 285 of Law No. 23 of 2014 explicitly stated that one of the causes of regional income, which is the original regional income is regional retribution. However, the regional government in forming regional regulations on regional retribution, which is an attempt to extract local revenue, can not be done excessively, which will result in a burden for residents as a result of the diversity of regional retribution. This is as confirmed in Article 286 of Law No. 23 of 2014, that: (1) Regional taxes and retribution are stipulated by laws which are further regulated by regional regulations; (2) Regional Governments are prohibited from making retribution or other designations outside those stipulated in the law.

The existence of the cancellation of thousands of provincial and regency / city regulations by the Ministry of Home Affairs has caused reactions from various parties so that several regency / city governments submitted requests for judicial review of Law No. 23 of 2014 concerning regional government relating to the Government's authority to cancel the regional regulation. Upon the submission of the petition, the Constitutional Court (MK) No. 56/PUU-XIV/2016 in its decision stated that "the authority of the Governor and the Minister to cancel the regulations of the regency or city is contrary to the Constitution" and to be able to cancel the

\footnotetext{
10 Popy Rakhmawaty, 'Pembatalan Perda Jangan Semata Urusan Investasi', SINDOnews.com, accessed 28 June 2020, https://nasional.sindonews.com/berita/1118608/12/pembatalan-perdajangan-semata-urusan-investasi.
} 
regulations of the regency / city can only be done with a Judicial Review by the Supreme Court (MA). This decision is undoubtedly a breakthrough law intended to end the dualism of the regional regulation testing that has been running.

This study uses normative and empirical juridical approaches. Both approaches are carried out to solve the problem so that research objectives can be achieved. In a normative juridical approach, the problem will be analyzed by reviewing and interpreting matters that are categorized theoretically in legal texts relating to legal principles that contain legal doctrines, conceptions, views, laws and regulations, and legal systems that are relevant to the object research. The empirical juridical approach in research is carried out to solve research problems by first examining secondary data, then examining primary data in the field. This empirical juridical approach is carried out by collecting and finding information and data in field studies with samples from several regional / city governments whose regional regulations on retribution was canceled by the Government (Ministry of Home Affairs) in 2016 and 2017. In operation, the normative juridical approach is carried out with literature studies while the empirical juridical approach is carried out by interviews with competent sources and related to research originating from the Legal Section at the Kuningan, Sumedang and Bandung Regency Secretariat Offices and at the Kuningan and Sumedang Regional Revenue Management Offices. Data obtained by researchers, then analyzed using qualitative analysis. This qualitative analysis is carried out to analyze normative (juridical) aspects through a descriptive analysis method. In this descriptive analysis method, researchers try to decipher or describe the data obtained and connect to get a general conclusion by the object of research.

\section{Mechanism of Formation of Regional Regulation on Retribution Implemented by Regencies / City Governments in West Java}

The 1945 Constitution of the Republic of Indonesia Article 1 paragraph (1) states that the Republic of Indonesia is a Unitary State in the form of a Republic. Then Article 18 Paragraph (1) determines: The Unitary State of the Republic of Indonesia is divided into provinces, and the province is divided into regencies and cities, each of which has a regional government, which is regulated by law.

The division of state territory into provincial areas and within provincial areas consists of Regency / City regions, as well as regional governments, as regulated in Paragraph (2) "The provincial, regency and city-regional governments regulate and manage their governmental affairs according to the principle of autonomy and duty of assistance ". As for completeness of the administration of Government and constitute an element of the regional government, a regional people's representative body was formed, as determined in Paragraph (3) "The provincial, regency and cityregional government have a Regional People's Representative Council whose members are elected through general elections". Then the Governors, Regents, and Mayors, respectively as provincial, regency, and city-regional government heads, are democratically elected.

In the administration of regional government, the regional government is given the broadest possible autonomy, except for governmental affairs, which are determined by law as the affairs of the Central Government. In the context of implementing broad autonomy in the regions, the regional government has the 
right to stipulate regional regulations and other regulations to carry out autonomy and assistance tasks.

Based on the provisions of Article 1, number 10 of Law Number. 32 of 2004 concerning Regional Government, referred to as regional regulation, is provincial regulation or regency / city regional regulation. Further provisions regarding this regional regulation are regulated in article 136 to article 149 of Law no. 32 of 2004. Regional governments made regional regulations to carry out regional autonomy within the unitary state of the Republic of Indonesia.

The existence of regional regulations is an oversight of the granting of authority to the regions in managing and managing their households because there are parts of regional affairs other than those stipulated in the law and must be regulated further by regional regulations. Regarding the authority to form regional regulations, it has been emphasized. UU no. 32 of 2004 Article 42 paragraph (1) letter a stipulates that: "DPRD has the duty and authority to form a regional regulation that is discussed with regional heads to obtain mutual agreement. Furthermore, it is emphasized again by Law No. 27 of 2009 concerning the MPR, DPR, DPD, and DPRD determined: Provincial DPRD has the duty and authority: to form provincial, regional regulations with the governor, discuss and approve draft regional regulations on provincial, regional income and expenditure budgets proposed by the governor, while the authority of the Regencies / City DPRD is affirmed in Article 344 it is determined: (1) Regencies / city DPRD has duties and authority, forms regencies/city regional regulations together with regents/mayors, discusses and approves draft regional regulations on regencies/city regional revenue and expenditure budgets submitted by regents/mayors.

The DPRD and the Regional Heads together determine the Regional Budget (APBD) and other regional regulations. The Regional Head leads the regional government to implement the APBD and other regulations. Besides that, the DPRD also conducts oversight. Against the Regional Head in implementing the APBD and other regional regulations and in the context of the tasks and authority of the Regional Head, it is directing and controlling the regional bureaucracy. Several tasks must be done: implementation of regional policies, enforcement of regional regulations, providing public services to residents, and collecting and processing information to then be submitted in the form of recommendations to the Regional Head. A region is an autonomous region as a government unit in the region and which has attributive authority authorized to make regulations to run its household. The authority to regulate is with the Regional Government and the Regional Parliament as the holder of the Regional Parliament function. Regional regulation is the implementation of the function of DPRD.

Regional regulations are all regulations made by the local government to implement other regulations that are higher in rank. ${ }^{11}$ Therefore, the material on regional regulations, in general, includes, among others: 1) Matters relating to regional households and matters relating to regional government organizations; 2) Matters relating to duties and assistance Mendebewindl thus regional regulation is a legal product of the regional government in the context of implementing regional autonomy, namely exercising the right and authority to regulate and manage their

\footnotetext{
${ }^{11}$ Bagir Manan, ed., Menyongsong fajar otonomi daerah (Yogyakarta: Pusat Studi Hukum, Fakultas Hukum, Universitas Islam Indonesia, 2001), 136.
} 
domestic affairs as well as regional regulation is legality to support the Provincial Government as an autonomous region. ${ }^{12}$

Law Number 10 of 2004 regulates several principles regarding regional regulation: 1) Regional Head establishes regional regulation with DPRD approval; 2) Regional regulation are formed in the implementation of autonomy, coadministration tasks, and further elaboration of higher legislation; 3) Regional regulation may not conflict with the public interest, other regional regulation, or higher statutory regulations; 4) Regional regulation may contain provisions for the imposition of law enforcement or criminal confinement fees for a maximum of six months or a maximum fine of five million rupiahs; 5) The Decree of the Regional Head is stipulated to implement the regional regulation; 6) Regional regulation and Decrees of Regulating Regional Heads are contained in regional sheets; 7) Regional regulation may appoint certain officials as investigating officers in violation of regional regulation (PPNS regional regulation and Decrees of Regional Heads).

\section{Principles for Forming Regional Regulations}

Based on Law Number 32 of 2004, the importance of the position of the DPRD is because it is an element of the regional government in the administration of regional government. The position of the DPRD as a Regional Legislative Body is equal and becomes a partner of the Regional Government, as well as carrying out the function of control or supervision of the Regional Government. Based on Law Number 32 of 2004, the duties and authorities of the DPRD are, among others: $:^{13}$ a) Form a Government Regulation that is discussed with the Regional Head for mutual agreement; $b$ ) Discuss and approve the draft regional regulation concerning Regional Revenue and Expenditures Budgets together with Regional Heads; c) Carry out oversight of the implementation of regional regulation and other legislation, Governor's Decree. Regents and Mayors, Expect Regional Revenue and Expenditures, Regional Government Policies, and International Cooperation in the Regions; d) Propose the appointment and removal of the Regional Head / Deputy Regional Head to the Presiders through the Minister of the Interior for the Provincial DPRD and to the Minister of the Interior through the Governor for the Regency / City DPRD; e) To elect the Deputy Regional Head in the event of a vacancy in the Deputy Regional Head; f) Provide opinions and considerations to the Regional Government on plans for international agreements in the region; g) Approve plans for international cooperation carried out by the Regional Government; h) Request a report on the accountability of the Regional Head in organizing regional government; i) Establish a Regional Head Election Supervisory Committee; j) Supervise and request KPUD reports in the holding of regional head elections; k) Approve plans for cooperation between regions and with third parties that burden the community and the region.

After Law Number 22 the Year 1999 is replaced by Law Number 32 the Year 2004, the principles for the establishment of regional regulation are determined as follows: the Regional Head determines (1) regional regulation after obtaining joint agreement from the DPRD; (2) regional regulation are formed in the context of

\footnotetext{
${ }^{12}$ Rosjidi Ranggawidjaja, Pengantar Ilmu Perundang-Undangan Indonesia (Bandung: Mandar Maju, 1998), 23.

${ }^{13}$ Manan, Menyongsong fajar otonomi daerah, 70.
} 
carrying out autonomy, co-administration tasks and further elaboration of higher laws and regulations with due regard to the characteristics of each region; (3) regional regulation may not conflict with the public interest or higher legislation; (4) regional regulation are formed based on the principle of formation of laws and regulations, (5) the public has the right to provide input verbally or in writing to prepare or discuss the regional regulation, (6). regional regulation may contain provisions for the imposition of law enforcement costs, or imprisonment for a maximum of six months or a maximum fine of Rp. 50,000,000 (fifty million rupiah). (7) Regional Head Regulations and/or Regional Head Decrees are stipulated to implement regional regulation. ${ }^{14}(8)$. regional regulation come into force after they are promulgated in regional news sheets. (9). regional regulation may indicate certain officials as certain investigative officials as investigating officials in violation of regional regulation (PPNS regional regulation); (10) Enactment. Regional regulation in the Regional Gazette and Regional Head Regulation in the Regional News.

A statutory regulation does not apply eternal, because of the development of society, then the regulation also changes or is declared invalid. Statutory regulation is declared invalid if: a) Canceled. The annulment of laws and regulations can significantly mean that the new laws clearly state that the old laws and regulations have been revoked. For example, Law No. 5 of 1974, replaced with Law No. 22 of 1999 concerning Regional Government. Besides that, the formation of regulation can be done secretly, meaning it does not clearly state that the regulation is revoked. Furthermore, if a rule arises that regulates something that was previously regulated by a previous regulation, it is declared no longer valid; $b$ ) The law is declared invalid if the validity period has passed; c) In reality, these laws and regulations cannot be enforced according to the times.

The existence of Regional Regulations on Taxes and Retributions is a logical consequence of the implementation of decentralization policies based on broad autonomy as regulated initially in Law Number 22 of 1999 and its successor to Law Number 32 of 2004 which has also been replaced by Law Number 23 of 2014 concerning Regional Government. This decentralization policy gives broad authority to the regions, including in terms of increasing Regional Original Revenues through Regional Taxes and Regional Retribution by Law Number 28 of 2009 concerning Regional Taxes and Regional Retribution.

\section{Cancellation of Regional Regulation based on Act Number 23 of 2014 concerning Regional Government}

Formation of regional regulation cannot be separated from supervision and control. This is related to the control of legal norms contained in legislation, through what is commonly referred to as the legal norm control mechanism (legal norm control mechanism). According to Jimly Asshiddiqie, there are 3 (three) forms of supervision/control (legal norms in) laws and regulations. First, juridical control, namely supervision/control of legislation through a material test (judicial review). In the Indonesian parliamentary system for the examination of Laws with the Basic Law, it becomes the authority of the Constitutional Court (Article 10 paragraph (1) of Law No. 24 of 2003 concerning the Constitutional Court. While

${ }^{14}$ Manan, 70. 
for testing of legislation under the Law Law on the Law becomes the authority of the Supreme Court (Article 31 of Law No. 14 of 1985 jo Law of Law No. 5 of 2004) Second, administrative control, namely supervision/control of statutory regulations by executives or administrative institutions that perform the function of "bestuur" in the executive field, for example, the President there are extraordinary things that do not allow the Act to be applied, the President has the authority to issue Government Regulations instead of Laws that "cancel" the enactment of the Law approved by the House of Representatives (for example Law No. 14 of 1992 concerning Road Traffic Third, control p political, namely supervision/control of legislation by political institutions such as parliament. In this case, the amendment of the Law through the right of the initiative as an amendment to the Act that was passed by the President.

Based on these legal norms contained in regional regulation are also not immune from the legal norm control mechanism. The authority of the Minister of Home Affairs and the Governor as the representative of the central government to cancel the APBD regional regulation as referred to in Article 251 of Law No. 23 of 2014, is a form of administrative control of the Ministry of Home Affairs that carries out the "bestuur" function. Thus, from this point of view, the validity of the authority of the Minister of Home Affairs and the Governor as the representative of the Central Government has a stronger basis, especially when viewed from the position of the Minister of Home Affairs as a higher official. The position of the Minister of Home Affairs and the Governor as the representative of the Central Government is higher, not only visible from the right products it produces, but also its position, which is higher than the DPRD and the Governor.

In-Law No. 23 of 2014, which replaces Law Number 32 of 2004 concerning Regional Government, there is a significant change regarding the increasingly clear authority to cancel the Provincial regional regulation, Regency / City regional regulation, Pergub and Perbup / Perwal by the Central Government. In connection with the cancellation, the principle matter is the regional obligation to deliver its legal products to the Central Government as well as restrictions or prohibitions on the contents of regional regulation or local regulations.

Article 249 of Law No. 23 of 2014 states that: 1) The Governor is obliged to submit Provincial regional regulation and governor regulations to the Minister no later than 7 (seven) days after stipulation; 2) The governor who does not submit the Provincial regional regulation and governor's regulation to the Minister, as intended in paragraph (1) shall be subjected to administrative sanctions in the form of a written warning from the Minister; 3) The Regent / Mayor must submit Regency / City regional regulation and Regents / Mayor Regulations to the Governor as the representative of the Central Government no later than 7 (seven) days after stipulation; 4) Regents/mayors who do not submit Regulations of the Regency / City Governments and Regents / Mayors to the Governor as the representative of the Central Government as referred to in paragraph (3) are subjected to administrative sanctions in the form of a written warning from the governor as a representative of the Central Government.

Concerning restrictions or prohibitions on the contents of regional regulation and local regulations are prohibited contrary to the provisions of higher laws, public interests, and/or morality. Provincial regional regulation and regional regulation that are contrary to general provisions, and/or decency are canceled by the Minister 
and Regulations of the regency/city government, and regent/mayor regulations that are contrary to the provisions of higher laws, public interests, and/or the governor canceled decency as a representative of the Central Government. To strengthen the above provisions, a sanction is imposed on the regions that are not willing to implement the Central Government Decree to cancel the regional regulation and local Regulation. These sanctions can be in the form of administrative sanctions and/or sanctions for delaying the evaluation of the draft regional regulation. The administrative sanction itself is in the form of being imposed on regional heads and DPRD members in the form of actions not to be paid for financial rights that are regulated in the provisions of legislation for 3 (three) months. Sanctions for delaying the evaluation of the draft Government Regulation in the form of not being stipulated when the Regional Government administrators are still filing objections to the President for Provincial regional regulation and to the Minister for Regency / City regional regulation. If in the case of provincial or district/city Regional Government administrators still impose regional regulation on regional taxes and/or regional retribution that are canceled by the Minister or canceled by the governor as a representative of the Central Government, sanctions may be postponed or withheld DAU (general allocation fund) and/or DBH (profit-sharing fund) for the region concerned.

\section{Cancellation of Provincial Regional Regulations, Regency / City Regional Regulations, Governor Regulations, and Regents Regulations / Mayor Regulations by the Supreme Court}

The Supreme Court in exercising judicial power as an attributive authority determined in Article 24A paragraph (1) of the 1945 Constitution, Article 11 section (2) letter b of Law Number 4 of 2004 concerning Judicial Power (Law No.4 of 2004), Article 31 Paragraph (2) of Law Number 5 of 2004 concerning Amendment to Law No. 14 of 1985 concerning the Supreme Court,${ }^{15}$ Article 31A of Law Number 3 of 2009 concerning Second Amendment to Law Number 14 of $1985,{ }^{16}$ concerning the Supreme Court; and Article 1 of the Supreme Court Regulation Number 1 of 2011 (formerly the Supreme Court Regulation Number 1 of 2004 concerning Material Judicial Rights, ${ }^{17}$ concerning Material Testing Rights. In the provision of these rules, the Supreme Court has the authority to conduct a review of the laws and regulations under the law.

The authority to examine the statutory provisions under the law against the law by the Supreme Court is then known as the judicial review or judicial review by the judiciary. The provisions of Article 24A paragraph (1) of the 1945 Constitution state that "the Supreme Court has the authority to adjudicate at the cassation level, examine the statutory provisions under the law against the law, and have other powers granted by law". Provisions in Article 20 paragraph (2) letter b of Law no. 48 of 2009 (previously Article 11 paragraph (2) letter b of Law No. 4 of 2004) states that the Supreme Court has the authority to review the statutory provisions under

\footnotetext{
${ }^{15}$ Law Number 5 of 2004 concerning Amendment to Law No.14 of 1985 concerning the Supreme Court, State Gazette R.I of 2004 Number 9 and Supplement to R.I Sheet Number 4355.

${ }^{16}$ Law Number 3 of 2009 concerning the Second Amendment to Law Number 14 of 1985 concerning the Supreme Court, State Gazette R.I Year 2009 Number 3 and Supplement to R.I Sheet Number 4958.

${ }^{17}$ Supreme Court Regulation No. 1 of 2001 concerning Material Testing Rights
} 
the law against the law. The provisions of Article 20 paragraph (3) of Law Number 48 of 2009 (previously Article 11 paragraph (3) of Law Number 4 of 2004) states that the statement does not apply legislation as a result of testing as referred to in paragraph (2) letter b, can be taken both in the cassation level examination or based on a request directly to the Supreme Court.

The provisions of Article 31 of Law Number 14 of 1985 (amended the latest by Law Number 3 of 2009 concerning the Second Amendment to Law Number 14 of 1985 concerning the Supreme Court) which states that: 1) The Supreme Court has the authority to examine the laws and regulations under the law against the law; 2) The Supreme Court declares illegitimate statutory provisions under the law for reasons that contradict the higher laws, or their formation does not meet the applicable regulations. The regulations of Article 31A paragraph (1) of Law Number 14 of 1985 (amended the latest by Law Number 3 of 2009) which states that: 1) Application for judicial review of legislation under the law on the law is submitted directly by the applicant or his attorney to the Supreme Court and made in writing in the Indonesian language. Provisions in Article 9 paragraph (2) of Law Number 12 the Year 2011 which states that: If a statutory regulation under the Act is alleged to conflict with the Law, the examination is conducted by the Supreme Court.

The authority of the Supreme Court to examine the three types of regulations above is contained in several laws and regulations. Starting from the constitutional basis in Article 24A paragraph (1) of the 1945 Constitution, then Article 11 paragraph (2) letter b of Law Number 4 of 2004 concerning Judicial Power23, subsequently Article 31 paragraph (2) of Law No. 5 of 2004 concerning Amendments to Law Number 14 of 1985 concerning the Supreme Court, 24 determining the standard size of a regulation under the law can be canceled, on the grounds of 1) because it contradicts the higher statutory regulations (material aspects); or 2) the formation does not meet the applicable provisions (formal elements).

To exercise the authority to examine the legislation, the Supreme Court has issued a Supreme Court Regulation Number 1 of 1999 concerning Material Judicial Rights, which is declared invalid and replaced with Supreme Court Regulation Number 1 of 2004 and then-Supreme Court Regulation Number 1 of 2011 concerning Rights Material Test. Supreme Court Regulation No. 1 of 2011 narrowed the authority of testing by the Supreme Court, which by the Constitution and the law was given the authority to examine the material and formal laws and regulations, to only conduct material testing of the material contained in the legislation. This means that the Supreme Court does not examine or examine the formal aspects of the formulation and formation of legislation under the law. Such conditions seem to act outside the authority, namely limiting one's authority, which is also part of legal obligations and legal certainty itself.

Closely related to the function of the Supreme Court, which is judicial (justitielefunctie), the authority of the Supreme Court to examine Regional Regulations was born from an authority called judicial review. In such circumstances, the Supreme Court is a judicial institution tasked with resolving conflicting norms arising from the birth of a product of legislation, including Regional Regulations. In carrying out such functions, the Supreme Court is passive in waiting for the submission of objections from interested parties in the regions. 
Implications of the Constitutional Court Decision Number 137/PUU-XIII/2015 and Decision Number 56/PUU-XIV/2016 concerning Cancellation of Provincial Regional Regulation, Regency/City Regional Regulation, Governor's Regulations and Regents Regulations/Initial Regulations

As a system of statutory regulations, the unity of the legal order should be no conflict between the rules of legal norms with each other. In practice, it cannot be denied that conflicts between legal norms often occur. This can occur because the legal organs that are authorized to make legal norms create conflicting norms between one legal norm with other legal norms. To conflict between legal norms can be tested (Toetsingsreview). Testing can be done through the ordinary way (ordinary way) by issuing new legal norms (legislation) and can also be done extraordinarily (extra-ordinary way), namely through the appointment of separate organs through the constitution as well as through a "judicial review ".

Differences in the testing of legislation also occur at the level of the terminology and legal tradition approach. In terminology, the term testing rights are paired with the term "Toetsingsrecht" which appears in the Netherlands and is also known in "civil law" countries. In "Anglo Saxon" countries, the developing terms are "judicial review" and "constitutional review". Countries in the "Anglo Saxon" family do not recognize the term "toetsingrecht". In its development, the terms "judicial review" and "constitutional review" are also used in "civil law" countries such as Germany and France. ${ }^{18}$

During this special examination of the legislation under the law, there is a dualism of the authority of the test between the government, in this case, the Ministry of Home Affairs and the Governor through "executive preview and executive review" with the Supreme Court through "judicial review" which has caused sufficient legal polemic complex. Testing regional regulation through the Supreme Court has a constitutional basis of legitimacy that is strong enough to rely directly on the authority granted by the 1945 Constitution in conjunction with Law No. 5 of 2004 in conjunction with Law No. 3 of 2009 in conjunction with Law No. 12 of 2011 and Perma No. 1 of 2011. Meanwhile, the cancellation of regional regulation by the government through "executive review" rests on the provisions of Law No. 23 of 2014 jo Permendagri No. 80 of $2015 .^{19}$

Based on the different authority of the test, the Association of All Indonesian Regency Governments (APKASI) submits a judicial review to the Constitutional Court (MK) for Regulations of Regency / City and Regent Regulation / Early Regulation. While AbdaKhair Mufti et al. filed a judicial review to the Constitutional Court for Provincial regional regulation that contradicted Article 251 paragraph (2), paragraph (3), paragraph (4), and paragraph (8) of Law No. 23 of 2014 against Article 18 paragraph (6), Article 28D paragraph (1), and Article 24A paragraph (1) of the 1945 Constitution. Through Decision Number 137 / PUU-XIII / 2015 states Article 251 of Law Number 23 the Year 2014 concerning Regional Government related to the authority to cancel Regency / City regional regulations can no longer be canceled by the Minister of Home Affairs or the Governor.

\footnotetext{
18 Jimly Asshiddiqie, Model-model pengujian konstitusional di berbagai negara (Jakarta: Mahkamah Konstitusi RI, Sekretariat Jenderal dan Kenpaniteraan MKRI, 2006), 73.

${ }_{19}$ King Faisal Sulaiman, Teori Peraturan Perundang-Undangan Dan Aspek Pengujiannya, Cet. 1 (Yogyakarta: Thafa Media, 2017), 263.
} 
The Constitutional Court in its ruling stated that the phrase "district/city and regional regulations" in the provisions of Article 251 paragraphs (2) and (4), the phrase "district/city and/or regional regulations" in Article 251 paragraph (3), and the phrase "The organizer of the regency/city government cannot accept the decision to cancel the regency/city regulation and" Law Number 23 of 2014 concerning Regional Government is contradictory to the 1945 Constitution of the Republic of Indonesia and has no binding legal force. Furthermore, completing Decision Number 137 / PUU-XIII / 2015, the Constitutional Court through Decision Number 56 / PUU-XIV / 2016 states that the central government no longer has the authority to cancel provincial, regional regulations.

MK through Decision Number 137 / PUU-XIII / 2015 and Decision Number 56 / PUU-XIV / 2016 which states that the authority of the Minister of Home Affairs and the Governor as the representative of the central government in canceling the Provincial Government Regulation, Pergub, Unconstitutional or contradictory Government Regulations with Article 18 paragraph (6), Article 28D paragraph (1), and Article 24A paragraph (1) of the 1945 Constitution. ${ }^{20}$

So that in the absence of the authority of the Minister of Home Affairs and the Governor as the representative of the central government in canceling the Provincial regional regulation, Governor Regulation, Regency / City regional regulation and only having that authority at the Supreme Court, the impact of the decision will occur. On one side of the Constitutional Court's decision, there is a positive side, namely the existence of legal certainty over the authority to cancel regional regulation products. Previously there was a dualism of the authority to examine regional regulation between the government, in this case, the Ministry of Home Affairs and the Governor through an "executive review" with the Supreme Court through a "judicial review". Then the authority to revoke Provincial, Pergub, and Regency / City regional regulation is only at the Supreme Court. So that the Government, in this case, the Minister of Home Affairs and the Governor as the representative of the central government, only conducts an "executive preview" of the draft regional regulation that has not been established or promulgated.

But on the other hand, there is an impact that becomes the material of thought that must be resolved, that is: First, In the absence of cancellation of Provincial regional regulation and Regency/City regional regulation by the Central Government which contradicts the provisions of the higher laws, public interests, and/or decency, the Central Government only has preventive supervision or "executive preview" "Which was done before the draft regional regulation was established. The form of preventive supervision is based on Law No. 23 of 2014 and Permendagri No. 80 of 2015, namely carried out by evaluating and facilitating. The evaluation it self is carried out on the draft regional regulation RPJPD, RPJMD, $\mathrm{APBD}$, changes in the APBD, accountability for implementing the APBD, regional taxes, regional retribution, regional spatial planning, industrial development plans, and formation, elimination, merging, and/or changing status Villages become villages or villages become villages. While facilitation is carried out on draft regional regulation other than those evaluated. The evaluation and facilitation will only take the form of recommendations given by the Minister of Home Affairs or

\footnotetext{
${ }^{20}$ Indonesia Constitutional Court Decision No.137 / PUU-XIII / 2015 concerning Judicial Review of Law 23 of 2014 concerning Regional Government
} 
the Governor as the representative of the central government. The recommendation can later be used as a material for consideration by the regional government whether to continue the draft regional regulation to be stipulated as a regional regulation or not be continued as a regional regulation. If the regional regulation or local regulation is recommended to be discontinued because it contradicts the provisions of the higher laws, public interests, and / or decency, then the local government continues until the stipulation of the regional regulation, the regional regulation with all the consequences which is contrary to the provisions of the higher laws, general interests, and / or decency.

Second, The attribution authority of the Supreme Court could theoretically be delegated to the judicial institution underneath. Regarding delegation authority, this is still a problem in Indonesia, namely the Supreme Court is bound by the principle that "a person or institution that receives delegation authority must exercise that authority himself, may not be sub-delegated further (non-delegate delegate delegates) ). If the Supreme Court is not allowed to delegate as further authority to other institutions, then this will be very burdensome for people in disadvantaged areas with the enactment of Government Regulation or Regional Head Regulation, where they must submit material test rights to the Supreme Court in the Jakarta. On the other hand, Supreme Court has also still had arrears on the case at the cassation level, which must be implemented immediately. ${ }^{21}$

The Right to Test (Toestingrecht) both in the library and in practice, there are two kinds of testing rights (Toestingrecht), namely: The right to formal testing (formeleteotsingrecht): the authority to judge a legislative product such as a law, in the process of making it through the methods as determined/regulated in the prevailing laws or regulations. Formal testing is related to procedural issues and relates to the legality of the competencies of the institutions that make them. The right to formal trial is the authority to judge whether a legislative product such as a law, for example, is manifested through methods (procedures) as determined or regulated in applicable laws or regulations. For example, Regional Regulations are formed (established) by the Regional Representative Council / DPRD together with the Governor, Regent, or Mayor. A legal product cannot be called a Regional Regulation (Government Regulation) if it is only stipulated by the Governor, without approval from the DPRD.

The right to test material (materieletoestingrecht): an authority to investigate and assess the contents of whether a statutory regulation is appropriate or contrary to regulations of a higher degree, (lex superior derogate lex inferior), and whether a power specific (verordenendemacht) has the right to issue a specific regulation. Material testing is related to the possibility of material conflict between regulation and other regulations, which are higher or related to the specificities of a rule compared to generally accepted norms..

Judicial review cases by the Supreme Court only cover the material aspects, namely evaluating whether the legislation being tested is contradictory or not with higher laws. While the formal elements are not in the test, assess, namely, statutory regulation of its formation through the methods as determined/regulated in the applicable legislation or not. This is based on the law of law contained in the Supreme Court Regulation (PERMA) No. 1 of 2011 concerning the Right to Judge

${ }^{21}$ Sukardi, Pengawasan Dan Pembatalan Peraturan Daerah (Yogyakarta: Genta Publishing, 2016), 72. 
Material. In reflecting on the Constitutional Court, special rules regarding material testing and formal testing have been incorporated and outlined in the Constitutional Court Regulation (PMK) Number: 06 / PMK / 2005 Concerning Guidelines for Procedure in Case Testing of Laws. As is known, that testing of statutory regulations under the law is divided into two, namely material testing and formal testing. Thus the Supreme Court Regulation (PERMA) No. 1 of 2011 narrowed the authority of testing by the Supreme Court, which by the Constitution and the law was given the authority to examine the material and formal laws and regulations, to only conduct material testing of the material contained in the legislation. This means that the Supreme Court does not examine or examine the formal aspects of the formulation and formation of legislation under the law. The Supreme Court Judge's decision only considers the aspects of authority and substance that are based on higher laws, while procedural aspects are not considered. ${ }^{22}$

Also, it is necessary to pay attention to the weaknesses of not setting the time limit for the process of testing the legislation, how long is the appointment of judges to be carried out and how long is the maximum time that can be used by the panel of judges to examine cases of legislative testing. On the one hand, there is no time limit for the process of testing the laws and regulations by the Supreme Court; on the other hand, the Supreme Court limits the time for citizens' rights to file objections. The absence of the statutory time limit for judicial review by the Supreme Court has the potential to make the Regional Regulation being tested neglected by the legal certainty of its application in the regions.

Also, the consequences of the Constitutional Court's ruling revoked Article 251 paragraph (2), paragraph (3), paragraph (4), and paragraph (8) of Law No. 23 of 2014 has implications for other articles in Law No. 23 of 2014 and also the regulations under it namely Permendagri No. 80 of 2015. As stipulated in Article 252 of Law No. 23 of 2014, which imposes sanctions on regions that are not willing to implement the Central Government Decree in canceling Government and Regional Regulation in Article 251 of Law No. 23 of 2014 was $\neg$. So that the provisions in Article 252 of Law No. 23 of 2014 cannot be enforced. The same thing also has implications for Permendagri No. 80 of 2015 contained in Chapter XI regarding the Cancellation of Regional Legal Products in the form of Regulations.

With the Decision of the Constitutional Court Number 137 / PUU-XIII / 2015 and Decision Number 56 / PUU-XIV / 2016, the central government no longer has the authority to do the banning of regional regulations, both provincial and district/city regulations. At a glance, this decision has revoked the spirit of the authority to revoke the statutory provisions under the law to the Supreme Court, as stated explicitly in the provisions of Article 24A of the 1945 Constitution of the Republic of Indonesia. However, if it is thoroughly examined, this decision precisely does not fully restore the authority to revoke statutory regulations under the law to the Supreme Court. This is because the decision of the Constitutional Court only applies to provincial and district/regional city regulations, while regional head regulations (governor and regent / major regulations) can still be canceled by the Minister of Home Affairs and the governor in stages.

\footnotetext{
${ }^{22}$ Sukardi, 145.
} 


\section{The Effect of Revocation of Retribution Regulations on Regional Finances in Regencies / Cities in West Java}

The main characteristic that shows that an autonomous region is autonomous is that it lies in the financial capacity of the region. This means that an autonomous region must have the authority and ability to explore its own financial resources, manage and use its own finances which are sufficient to finance the implementation of its regional government. Dependence on central assistance must be as minimal as possible, so that Regional Original Revenue (PAD) especially taxes and levies must be the largest source of financial resources, supported by the Central and Regional financial balance policy as a basic prerequisite in the state government system.

In this regard, the optimization of $\mathrm{PAD}$ resources needs to be done to improve regional financial capacity. For this reason, intensification and extensification of subjects and objects of income are needed. In the short term the easiest and most immediate activity is to intensify the objects or sources of regional income that already exist, especially through the use of information technology. By doing the effectiveness and efficiency of local revenue sources or objects, it will increase the productivity of PAD without having to expand new sources or revenue objects that require a long study, process and time.

On the other side, as a sign the reason for the formation of Law (Law) No. 18 of 1997 concerning Regional Taxes and Regional retribution, on May 23, 1997, was to reduce the high-cost economy caused by too many types of fees imposed by the LG. UU no. 18 of 1997, aims to renew the system of regional retribution into a system that is simple, fair, effective, efficient, and involves the role of the community in financing regional development. Applicability of Law No. 18 of 1997, causing there to be several types of taxes and retribution that could potentially be lost.

Based on this, on December 20, 2000, Law No. 34 of 2000, concerning Amendments to the Law of the Republic of Indonesia No. 18 of 1997, concerning Regional Taxes and Retribution (Law No. 34/2000). This change is intended so that retribution can establish regional autonomy that is broad, real, responsible, and adjusts to the changing circumstances. UU no. 30 of 2000, giving the impact of the regional regulation, the new regional regulation regarding taxes and retribution, which can be unsettling to the public and/or business actors. ${ }^{23}$ This has created conditions that are not conducive to national economic development and investment.

Also, the new government regulations have led to retribution, which in turn have created a high-cost economy and have weighed on the national economy. In connection with these conditions, then on September 15, 2009, regional retribution were reorganized by the enactment of Law no. 28/2009. This law is applied to expand regional tax and retribution objects, as well as discretion in setting tariffs. Policy Law No. 28/2009 is implemented based on the principles of democracy, equity and justice, community participation, and accountability about regional potential.

\footnotetext{
23 A. Abimanyu et al., Evaluasi Pelaksanaan UU Nomor 34 Tahun 2000 Tentang Pajak Daerah Dan Retribusi Daerah (Jakarta: Depkeu RI, 2005).
} 
UU Nurul Huda, The Effect of Cancelation... | 81

Table 1 List of sample regencies/cities in West Java that were canceled

\begin{tabular}{|c|c|c|}
\hline NO. & Regency / CITY & $\begin{array}{c}\text { NAME OF THE GOVERNMENT } \\
\text { REGULATION }\end{array}$ \\
\hline 1 & Bandung district & $\begin{array}{l}\text { 1. No. } 4 \text { of } 2012 \text { concerning Terminal Retribution } \\
\text { 2. No. } 19 \text { of } 2013 \text { concerning Retribution } \\
\text { Extension Permits for Employing Foreign } \\
\text { Workers } \\
\text { 3. No. } 23 \text { of } 2011 \text { concerning nuisance permit } \\
\text { levies }\end{array}$ \\
\hline 2 & Purwakarta district & 1. No. 4 of 2012 concerning Terminal Retribution \\
\hline 3 & Cianjur district & $\begin{array}{l}\text { 1. No. } 14 \text { of } 2012 \text { concerning Building Permit } \\
\text { Retribution } \\
\text { 2. No. } 15 \text { of } 2012 \text { concerning nuisance permit } \\
\text { levies } \\
\text { 3. No. } 11 \text { of } 2014 \text { concerning General Mining } \\
\text { 4. No. } 1 \text { of } 2013 \text { concerning Telecommunication } \\
\text { Tower Control Retribution }\end{array}$ \\
\hline 4 & Kuning & $\begin{array}{l}\text { 1. No. } 21 \text { of } 2010 \text { concerning Retribution of } \\
\text { Regional Assets } \\
\text { 2. No. } 18 \text { of } 2010 \text { concerning Telecommunication } \\
\text { Tower Control Levy } \\
\text { 3. No. } 22 \text { of } 2013 \text { Retribution Reimbursement of } \\
\text { Identity Card Printing } \\
\text { 4. No. } 20 \text { of } 2009 \text { concerning the Implementation } \\
\text { of the Joint Telecommunication Tower }\end{array}$ \\
\hline 5 & Cirebor & $\begin{array}{l}\text { 1. No. } 21 \text { of } 2009 \text { concerning Retribution of } \\
\text { Regional Assets } \\
\text { 2. No. } 8 \text { of } 2011 \text { concerning Telecommunication } \\
\text { Tower Control Retribution } \\
\text { 3. No. } 3 \text { of } 2012 \text { concerning Business Service } \\
\text { Levies } \\
\text { 4. No. } 7 \text { of } 2011 \text { concerning Regional Business } \\
\text { Production Sales Levies } \\
\text { 5. No. } 5 \text { of } 2011 \text { concerning market service levies } \\
\text { 6. No. } 6 \text { of } 2011 \text { concerning Waste / Cleanliness } \\
\text { Service Retribution }\end{array}$ \\
\hline 6 & Bandung City & $\begin{array}{l}\text { 1. No. } 1 \text { of } 2009 \text { concerning the Implementation } \\
\text { and Retribution of Telecommunication Towers } \\
\text { in the City of Bandung } \\
\text { 2. No. } 12 \text { of } 2011 \text { concerning the Implementation } \\
\text { of Building Permit Levy and Map Fee } \\
\text { Reimbursement Fees } \\
\text { 3. No. } 15 \text { of } 2012 \text { concerning the Implementation } \\
\text { of the Telecommunication Tower and the } \\
\text { Contribution of Telecommunication Tower }\end{array}$ \\
\hline
\end{tabular}




\section{Management}

4. No. 19 of 2012 Nuisance Permit and Nuisance Permit Retribution

Source: Legal Division of the Regency / City Regional Secretariat in West Java

The data above shows several regional regulation that have been canceled. The cancellation is more or less certainly has an influence on regional finances. Zulka stated that to implement the elimination of retribution, the central government needed to create a legal basis for cancellation of the regional regulation of retribution, which had been used as a guideline by the regions. ${ }^{24}$ In addition, nationally the data shows that cancellation of 3.143 regional regulation on June 13, 2016, received a lot of reactions from various parties. Chair of the MPR, Dr. Zulkifli Hasan, for example, strongly agreed with the cancellation of regional regulation. The reason is if the regional regulation hinders investment and abducts the community, why should it be maintained. However, most responded negatively to the cancellation of regional regulation. As a sample, the results of the author's interview with the Head of the Kuningan Regency Revenue Service, stated that the removal of the Kuningan Regency regional regulation would have an impact on the loss of potential local revenue (PAD). The loss of potential local revenue (PAD) certainly has an effect on the revision of the regional budget allocation. Although some regional regulation that were revoked were declared contrary to other regulations. Among them is related to the revocation of Regional Regulation No. 22 of 2013 concerning Retribution Reimbursement of KTP Print and Civil Registry Deed, received the support of the majority of factions in the DPRD because the retribution are not in line with Law Number 23 of 2006.

Speaking of roles, the existence of retribution is inseparable from the implementation of regional autonomy and decentralization. Decentralization is a tool to achieve one of the objectives of the state, especially in order to provide better public services and create a more democratic process of returning public decisions. Therefore, the role of regional retribution cannot be underestimated. In autonomy, loss of retribution means the loss of one of the pillars of regional autonomy. Retribution can be regarded as a pillar because it absolutely reflects the independence of an area in managing its household affairs. Thus, the cancellation of regional regulation on retribution has an impact on regional financial conditions. The cancellation of various types of regional regulation such as those presented in the table above shows the region has the potential to lose its PAD source.

Regional governments will not be able to carry out their functions effectively and efficiently without sufficient costs to provide services and development. This financial aspect is one of the basic criteria for knowing the region's real ability to manage its own households. Therefore, the loss of retribution also affects the level of effectiveness and efficiency in the administration of local government. Furthermore, there are several patterns and strategies that can be done in increasing $\mathrm{PAD}$, especially on regional taxes and retribution to be able to effectively boost PAD which do not conflict with regulations or economic norms: 1) Simplification of systems and procedures for regional taxes and retribution; This simplification is

\footnotetext{
${ }^{24}$ A. Zulka, 'Penghapusan Retribusi Perikanan Untuk Tingkatkan Produksi', 2009, http:// koranjakarta. com/berita-detailterkini.php?id=24055.
} 
important in anticipation of overlapping rules. With simple rules, the regions can easily understand and embody regulations related to the taxes and retribution; 2) Availability of regulations at the regional level; All forms of levies must be based on clear rules. So as not to become a illegal levy.

\section{Conclusion}

Based on the results of research that has been done, it can be concluded as follows: Mechanism for the Formation of Government Regulation Levies Conducted by Regency / City Governments in West Java in its preparation is carried out through SOP according to the following stages: The draft of the Regional Regulation to be formed is proposed by the Regional Work Unit (SKPD); then the regional regulation draft is then conveyed to the Regional Secretary through the Legal Department accompanied by a letter of introduction signed by the head of the SKPD; after deregister, the proposed regional regulation draft is included in the Regional Formation Program (Propem Regional Regulation) which has been stipulated in the Decree of Regency / City or Provincial DPRD; After correction and review, the Draft is returned to the proposing SKPD for discussion with the relevant Work Unit by the material to be regulated (finalization of the regional regulation draft); In the context of fostering and supervising regional policies, the regional regulation can be conveyed to the governor for consideration, after correction, study and consideration from the governor, the Legal Department then prepares a regional regulation and an introductory letter to be signed by the regent. The regional regulation are conveyed to the Regional Secretary through the relevant Regional Secretaries to get advice and considerations. Within 7 (seven) days before the Plenary Session of Submission of regional regulation, on the day specified in the DPRD Banmus Meeting, the Legal Department submitted a copy of the Government's draft Regulation on Regulations of 55 copies to the DPRD through the DPRD Secretariat delivered with a Letter of Intent signed by the Regent (1 day). The Stages of Discussion Process of the regional regulation, which has been approved by the DPRD in a DPRD Decree, is submitted to the Legal Department accompanied by a Minutes of Meeting that has been compiled. Previously the DPRD Secretariat will make improvements to the substance of the material that has changed after discussion at the DPRD. The Legal Section will then submit the regional regulation to the Governor of West Java through a Letter of Introduction.

For regional regulation relating to APBD, Regional Taxes and Regional retribution and regional regulation, the Spatial Planning process must be evaluated to the Governor no later than 7 (seven) days after the DPRD Approval Decree is received. Then the Manuscript printed in 8 (eight) copies will be determined by the Regent / Mayor and published in the Regional News by the Regional Secretary; After the Regent and the Regional Secretary affix the following signature, the regional regulation is promulgated in the Regency / City Regional Gazette by giving the number and date of promulgation by the Regional Secretariat, the Regional Regulation is officially enacted in regency. The Central Government implements mechanisms for Testing and Canceling regional regulation on retribution before the Constitutional Court Decision based on Law Number 23 of 2014 concerning the regional regulation and by the Supreme Court. Furthermore, after the Constitutional Court's decision, the cancellation of the regional regulation 
rests on the Constitutional Court Decision Number 137 / PUU-XIII / 2015 and Decision Number 56 / PUU-XIV / 2016 concerning the Cancellation of Provincial regional regulation, Regency / City regional regulation, Governor Regulations, and Regents / Regents Regulations / Initial Rules. The existence of the cancellation of regional regulation on retribution has an effect on the loss of Regional Original Revenue (PAD) as a source of regional finance. The loss of retribution also affects the level of effectiveness and efficiency of local government administration, especially in aspects that are supported by the retribution budget.

\section{Bibilography}

A. Abimanyu, Purwiyanto, Makmun, and E. Subardi. Evaluasi Pelaksanaan UU Nomor 34 Tahun 2000 Tentang Pajak Daerah Dan Retribusi Daerah. Jakarta: Depkeu RI, 2005.

Agustino, Leo. 'Pembatalan 3.143 peraturan daerah: satu analisis singkat'. CosmoGov: Jurnal Ilmu Pemerintahan 3, no. 1 (29 April 2017): 14-35. https://doi.org/10.24198/cosmogov.v3i1.12405.

Asshiddiqie, Jimly. Konstitusi \& konstitusionalisme Indonesia. Jakarta: Konstitusi Press, 2006.

- Model-model pengujian konstitusional di berbagai negara. Jakarta: Mahkamah Konstitusi RI, Sekretariat Jenderal dan Kenpaniteraan MKRI, 2006.

Huda, Ni'matul. Desentralisasi asimetris dalam Negara Kesatuan Republik Indonesia: kajian terhadap daerah istimewa, daerah khusus, dan otonomi khusus. Bandung: Nusa Media, 2014.

Human Sekretariat Kabinet. 'Kemendagri Resmi Umumkan 3.143 Perda Yang Dibatalkan'. Sekretariat Kabinet Republik Indonesia, 21 June 2016. https://setkab.go.id/kemendagri-resmi-umumkan-3-143-perda-yangdibatalkan/.

Khalimy, Akhmad. 'Pencabutan Peraturan Daerah Dalam Timbangan Negara Hukum'. Mahkamah : Jurnal Kajian Hukum Islam 2, no. 1 (11 June 2017). https://doi.org/10.24235/mahkamah.v2i1.1617.

Mahkamah Agung RI. Laporan Tahunan Mahkamah Agung Republik Indonesia Tahun 2014. Jakarta: Mahkamah Agung, 2015.

- Laporan Tahunan Mahkamah Agung Republik Indonesia Tahun 2015. Jakarta: Mahkamah Agung, 2016.

Manan, Bagir, ed. Menyongsong fajar otonomi daerah. Yogyakarta: Pusat Studi Hukum, Fakultas Hukum, Universitas Islam Indonesia, 2001.

Martosoewignyo, Sri Soemantri. Hukum tata negara Indonesia: pemikiran dan pandangan. Bandung: Remaja Rosdakarya, 2014.

Popy Rakhmawaty. 'Pembatalan Perda Jangan Semata Urusan Investasi'. SINDOnews.com. $\quad$ Accessed 28 June 2020. https://nasional.sindonews.com/berita/1118608/12/pembatalan-perdajangan-semata-urusan-investasi.

Ranggawidjaja, Rosjidi. Pengantar Ilmu Perundang-Undangan Indonesia. Bandung: Mandar Maju, 1998.

Sukardi. Pengawasan Dan Pembatalan Peraturan Daerah. Yogyakarta: Genta Publishing, 2016. 
UU Nurul Huda, The Effect of Cancelation... | 85

Sulaiman, King Faisal. Teori Peraturan Perundang-Undangan Dan Aspek Pengujiannya. Cet. 1. Yogyakarta: Thafa Media, 2017.

Zulka, A. 'Penghapusan Retribusi Perikanan Untuk Tingkatkan Produksi', 2009. http:// koranjakarta. com/berita-detailterkini.php?id=24055. 